\title{
Fournier Gangrene Caused by Migration of Foreign Body from Rectum to Bladder
}

\section{Rektumdan Mesaneye Migrate Olan Yabancı Cisim Nedeniyle Gelişen Fournier Gangreni}

\author{
(D) Bayram DOĞAN1, id Abdullah İLKTAÇ11, id Mehmet Oğuz ŞAHIN², id Volkan ŞEN², id Cevper ERSÖZ1
}

${ }^{1}$ Bezmialem Vakıf University Faculty of Medicine, Department of Urology, İstanbul, Turkey

${ }^{2}$ Manisa State Hospital, Clinic of Urology, Manisa, Turkey

\begin{abstract}
Fournier gangrene is a serious infectious disease with high mortality and morbidity rates characterized by rapidly progressive skin necrosis. Immediate debridement of infected necrotic tissue and broad spectrum antibiotic therapy are the main principles of the treatment. Size of the debrided area, advanced age, colorectal predisposition and renal insufficiency are the factors affecting the mortality. In this case report, we present a rare case of Fournier gangrene caused by migration of foreign body from rectum to bladder.
\end{abstract}

Keywords: Fournier gangrene, rectum, bladder, foreign body

\section{ÖZ}

Fournier gangreni morbidite ve mortalite oranları yüksek, hızlı ilerleyen ve deri nekrozuyla karakterize ciddi bir enfeksiyöz hastalıktır. Acil olarak enfekte nekrotik alanların debridmanı ve geniş spektrumlu antibiyoterapi tedavinin ana prensipleridir. Debride edilen alanın büyüklüğü, ileri yaş, kolorektal predispozisyon varlığı, böbrek yetmezliği mortaliteyi etkileyen faktörler olarak sayılmaktadır. Bu olgu sunumunda çok nadir görülen rektumdan mesaneye migrate olmuş yabanci cisme bağlı Fournier gangreni anlatılmıştır.

Anahtar Sözcükler: Fournier gangreni, rektum, mesane, yabancı cisim

\section{Introduction}

Fournier gangrene (FG), first described in 1883, is rapidly progressive necrotizing fasciitis of perineal, perianal and genital areas that requires immediate treatment and rarely seen in women and children $(1,2)$. Although it was first described as idiopathic rapidly progressive gangrene of scrotum and penis in young healthy men, it is more common in middle-aged and older men.

\section{Case Report}

An 82-year-old male patient with inadequate self-care who was living alone was brought to our emergency service with decreased general condition. We could not obtain any information about patient's medical history. The body temperature of the patient was measured as $38.6{ }^{\circ} \mathrm{C}$ and laboratory tests revealed an urea level of $210 \mathrm{mg} / \mathrm{dL}$, creatinine level of $4 \mathrm{mg} / \mathrm{dL}$ and white blood cell (WBC) level of $21.17\left(10^{3} / \mathrm{uL}\right)$. Patient was diagnosed as having pneumonia and respiratory insufficiency and he was admitted to the intensive care unit as he required respiratory support and intravenous ceftriaxone treatment was started. Four days after admission, extended-spectrum beta-lactamase $(+)$ E. coli was isolated from urine culture and antibiotic treatment was changed to intravenous imipenem. Five days after admission, patient had a WBC level of $12.62\left(10^{3} / \mathrm{uL}\right)$ and was consulted to urology 
clinic after detection of a necrotic area in scrotum. Physical examination revealed a $5 \times 5 \mathrm{~cm}$ necrotic area with edema and crepitus and we decided to perform urgent surgical debridement.

The necrotic area in the scrotum was debrided. During debridement, a large defect starting from the middle part of corpus spongiosum and urethra was observed and transurethral foley catheter was exposed in this region. Irrigation was performed with physiological saline solution via urethral catheter and it was seen that solution was leaking from anus. On digital rectal examination, rigid, elastic, uniformly contoured tubular foreign body was palpated in rectum. A lower abdominal median incision was made to perform a colostomy. It was observed that bladder was severely contracted and indurated. After the incision of bladder, a rigid pipe $6 \mathrm{~cm}$ in length and $5 \mathrm{~mm}$ in diameter was detected. It was thought that tube was placed rectally and later migrated to bladder. Object was removed from bladder by applying a small force. Apart from the described object, a 25x20 $\mathrm{cm}$ transparent bag and 3 stones approximately $1 \mathrm{~cm}$ in diameter were removed from bladder and a $14 \mathrm{~F}$ Foley catheter was placed as cystostomy (Figure 1). Hartman colostomy was performed and a drain was placed inside abdomen. Wound dressings were changed daily and drain was removed in the postoperative $3^{\text {rd }}$ day. Patient could not recover from life support and died in the postoperative $11^{\text {th }}$ day.

\section{Discussion}

FG is a rapidly progressive infectious disease with high morbidity and mortality that requires immediate treatment and more

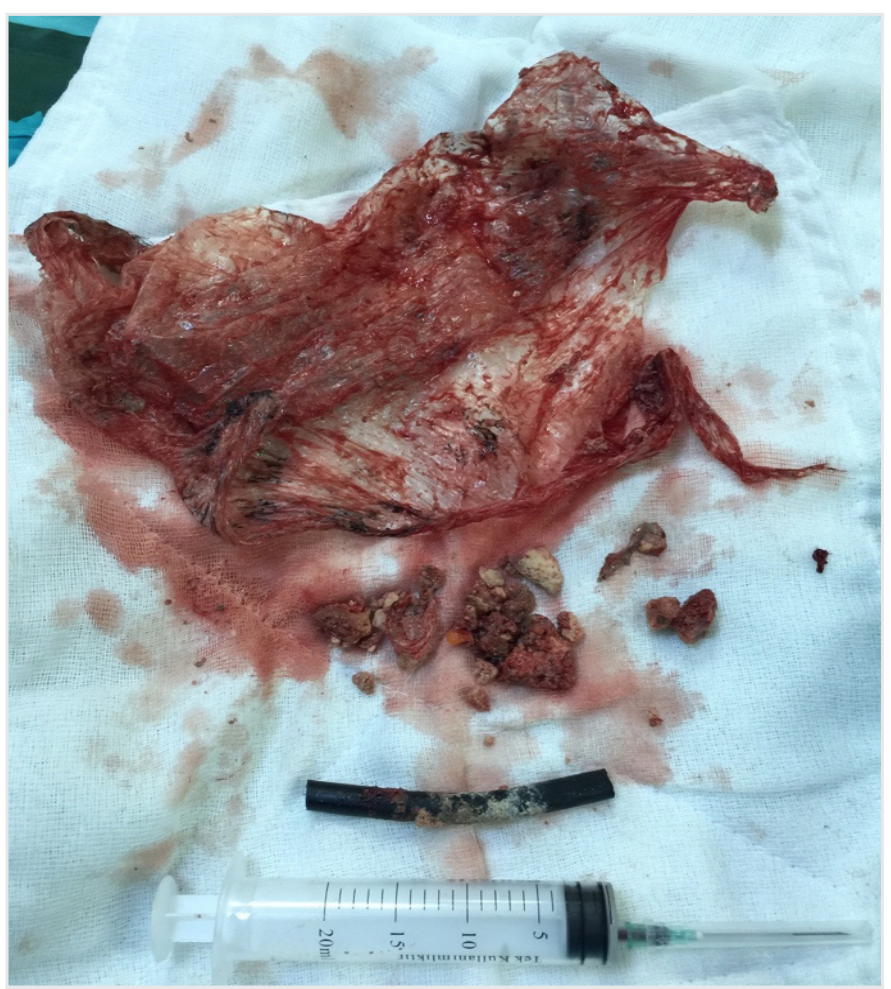

Figure 1. $25 \times 20 \mathrm{~cm}$ transparent bag, rigid pipe $6 \mathrm{~cm}$ in length and $5 \mathrm{~mm}$ in width, and 3 stones approximately $1 \mathrm{~cm}$ in diameter which were removed from bladder commonly observed in middle-aged and older men. Disease is usually originated from an infection in the anorectum, urogenital system or skin of the genital regions (3). It has been reported that many factors, such as Diabetes Mellitus, chronic alcoholism, lymphoproliferative diseases, cytotoxic drugs, immunosuppression, poor perineal hygiene, trauma, diseases that disturb urethral integrity as well as urinary tract infections and interventions to the urinary tract have predisposing effects on FG development $(4,5)$. Only one type of microorganism may cause the infection but usually different types of microorganisms coexist at the same time and Streptococcus, staphylococcus and escherichia species are the most common strains in cultures (6). Infection causes obliterative endarteritis in the peripheral vascular structures which results in deterioration of the blood supply of surrounding tissues and in necrosis but necrosis does not progress to the tissue below the fascia. Pain, swelling and hyperemia in the scrotal region are the most common symptoms, accompanied by fever and tachycardia (7). The diagnosis process begins with bringing the disease to mind. On physical examination, detection of skin necrosis and crepitus suggests FG. Imaging methods such as X-ray, ultrasonography and computerized tomography may contribute to the diagnosis by demonstrating air in the tissue. FG is a disease with high morbidity and mortality rates, patients with suspicion of FG should be closely monitored and immediately treated with broad spectrum antibiotics and surgical debridement of necrotic tissue (8). It should be remembered that if there is necrosis in the perineal region, colostomy may be necessary. There is evidence that hyperbaric oxygen therapy can be beneficial after debridement in some patients (9). Frequent and appropriate care of the wound, stabilization of the patient's hemodynamics, blood sugar regulation and nutritional support have significant effects on healing. The size of the debrided area, advanced age, presence of colorectal predisposition, and renal insufficiency are counted as factors affecting the reported mortality rate of 29\% (10). Although we performed adequate surgical debridement and gave broad spectrum antibiotics in our case, the patient died. We could not obtain any information about the medical history of the patient but presence of possible comorbidities and the fact that FG etiology was bladder and rectal injury had significant effect on mortality.

\section{Conclusion}

Although FG is rare disease that can be treated with immediate surgical debridement and broad spectrum antibiotics, it is a urological emergency with high morbidity and mortality rates. When there is a clinical suspicion of Fournier gangrene, radiological imaging is useful in detecting or excluding possible etiological factors even in patients without a history of genital or anal trauma.

\section{Ethics}

Informed Consent: Consent should be obtained for the orphaned, homeless street patient, and exits because of his illness.

Peer-review: İnternally and externally peer reviewed. 


\section{Authorship Contributions}

Concept: B.D., M.O.Ş., Design: V.Ş., Literature Search: C.E., B.D., A.İ., Writing: B.D.

Conflict of Interest: No conflict of interest was declared by the authors.

Financial Disclosure: The authors declared that this study received no financial support.

\section{References}

1. Fournier JA. Jean-Alfred Fournier 1832-1914. Gangrène foudroyante de la verge (overwhelming gangrene). Sem Med 1883. Dis Colon Rectum 1988;31:984-8.

2. Singh A, Ahmed K, Aydin A, Khan MS, Dasgupta P. Fournier's gangrene. A clinical review. Arch Ital Urol Androl 2016;88:157-164.

3. Eke N. Fournier's gangrene: a review of 1726 cases. Br J Surg 2000;87:718-28.

4. Corman JM, Moody JA, Aronson WJ. Fournier's gangrene in a modern surgical setting: improved survival with aggressive management. BJU Int 1999;84:85-8.
5. Pastore AL, Palleschi G, Ripoli A, Silvestri L, Leto A, Autieri D, et al. Multistep approach to manage Fournier's gangrene in a patient with unknown type II diabetes: surgery, hyperbaric oxygen, and vacuumassisted closure therapy: a case report. J Med Case Rep 2013;7:1.

6. Uluğ M, Gedik E, Girgin S, Celen MK, Ayaz C. The evaluation of microbiology and Fournier's gangrene severity index in 27 patients. Int J Infect Dis 2009;13:424-30.

7. Tahmaz L, Erdemir F, Kibar Y, Cosar A, Yalcın O. Fournier's gangrene: report of thirty-three cases and a review of the literature. Int J Urol 2006;13:960-7.

8. Furr J, Watts T, Street R, Cross B, Slobodov G, Patel S. Contemporary Trends in the Inpatient Management of Fournier's Gangrene: Predictors of Length of Stay and Mortality Based on Populationbased Sample. Urology 2017;102:79-84.

9. Gürdal M, Yücebaş E, Tekin A, Beysel M, Aslan R, Şengör F. Fournier Gangreni: 26 olgunun değerlendirilmesi. Türk Üroloji Dergisi 2001;27:492-7.

10. Enriquez JM, Moreno S, Devesa M, Morales V, Platas A, Vicente E. Fournier's syndrome of urogenital and anorectal origin. A retrospective, comparative study. Dis Colon Rectum 1987;30:33-7. 